\title{
OPEN Medical Geological assessment of fluoride contaminated groundwater in parts of Indo-Gangetic Alluvial plains
}

\begin{abstract}
Suresh Kumar ${ }^{1,3}$, Rambabu Singh ${ }^{2}$, A. S. Venkatesh ${ }^{3 *}$, G. Udayabhanu ${ }^{4}$ \& P. R. Sahoo ${ }^{3}$
As drinking water is considered as a major pathway of exposure to fluoride in the human body, an endeavor has been made for the assessment of the non-carcinogenic health risk by using hazard quotient ( $\mathrm{HO}$ ) of fluoride for males, females, and children separately in fluoride affected ground water areas of Indo-Gangetic Alluvial Plains. The study suggests that children groups are more prone to the non-carcinogenic risk of fluoride in the area as $\mathrm{HO}$ for fluoride is more than unitary in $44 \%$ (Premonsoon) and 38\% (Post-monsoon) samples respectively. Field survey conducted in fluoride-affected villagers of the study area portrays cases of mottling of teeth and bone deformities depending on the duration and dosage of fluoride consumption. Petrographic observations of host rocks coupled with molar ratios of chemical species studies exemplify that weathered material developed over the granitegneiss, mica-schist, amphibolite, granitic intrusive and pegmatite veins due to weathering and extensive water-rock interaction resulting higher concentration of fluoride in groundwater. Likewise, the base exchange index ( $r 1)$ and meteoric genesis index $(\mathrm{r} 2)$ advocates that most of the samples belong to $\mathrm{Na}^{+}-\mathrm{HCO}_{3}{ }^{-}$type and meteoric origin respectively, and substantiate longer residence time of water along with solute acquisition processes are responsible for elevated fluoride in groundwater. It is, therefore, solar energy-driven electrolytic de-fluoridation technology ought to be provided on a priority basis to the affected inhabitants besides the implementation of rainwater harvesting schemes for mitigation/ dilution of elevated fluoride concentration.
\end{abstract}

Several clinical studies and researches have been conducted to find out the impact of fluoride concentration in drinking water on human health. It is a well-known fact that fluoride $\left(\mathrm{F}^{-}\right)$at low concentration $(<0.5 \mathrm{mg} / \mathrm{L})$ induces dental caries, which enhances the risk of tooth decay ${ }^{1,2}$. On the other hand, ingestion of excessive fluoride imparts adverse effect on human health ${ }^{3}$. It is a well-established fact that elevated $\mathrm{F}^{-}$concentration in drinking water is linked to dental and skeletal fluorosis depending on the amount of intake and duration of exposure ${ }^{4,5}$. Excessive fluoride can also damage structure, function and metabolism of soft tissues such as kidney, liver, lung and testicles ${ }^{6-9}$. Various clinical studies suggest that ingestion of excessive fluoride promotes physiological dysfunctions like mutagenesis, immune suppression, carcinogenesis and growth retardation ${ }^{3,10}$. At times, higher concentrations of fluoride can also promote neuro-toxicological effects ${ }^{11,12}$. Several studies indicate that exposure of excessive fluoride does impart the vulnerable effect on the mental ability of the children. Choi et al. ${ }^{13}$ suggests that children with exposure to high fluoride were found with significantly lower IQ compared to children residing in low fluoride areas ${ }^{13}$. Fluoride easily reaches the placenta, and exposure to fluoride may permanently harm the foetus ${ }^{14}$. In the human body, the thyroid gland is the most sensitive tissue to the fluoride and exposure to fluoride raises TSH (thyroid stimulating hormone) concentration and decreases $\mathrm{T}_{3}$ and $\mathrm{T}_{4}$ concentration, thereby resulting in hypothyroidism ${ }^{15,16}$. In several studies, it has been pointed out that prolonged exposure of fluoride from drinking water does develop insulin resistance in human beings ${ }^{17,18}$. Excessive consumption of fluoride ultimately leads to hyperglycemia and impaired glucose tolerance ${ }^{19,20}$. While some studies showed that exposure to high fluoride may induce adverse impact on human reproductive system, leading to infertility problems and low

\footnotetext{
${ }^{1}$ Central Ground Water Board, Patna, India. ${ }^{2}$ Central Mine Planning and Design Institute Limited, Bilaspur, India. ${ }^{3}$ Department of Applied Geology, Indian Institute of Technology, (Indian School of Mines), Dhanbad, India. ${ }^{4}$ Department of Chemistry, Indian Institute of Technology (Indian School of Mines), Dhanbad, India. *email: asvenkatesh@iitism.ac.in
} 
body weight of neonates ${ }^{3,21,22}$. Osteosarcoma is known as a potential cancer target site due to fluoride deposition in bone $\mathrm{e}^{23,24}$. Cohn (1992) observed that the association of fluoride in public water with an increased incidence of osteosarcoma in young males ${ }^{25}$.

Ingestion of fluoride to human body, mainly occurs via, water and through other food and hygiene related foodstuffs, drugs, toothpaste. Among these, drinking water is the most prominent source of human contact with fluoride ${ }^{26}$. About $90 \%$ of the ingested fluoride in drinking water is absorbed, particularly from the gastrointestinal tract when the fluoride concentration increases by $1 \mathrm{ppm}^{27}$. On the contrary, only $30-40 \%$ of fluoride from food sources gets absorbed in the digestive system ${ }^{28}$. Hence, it is essential to identify the places of excessive fluoride concentration in groundwater and to assess health risk of exposure to fluoride. Health risk is an important assessment method applied to examine the real risk on human health resulting from consumption of specific chemical agents during specified time period ${ }^{29}$. The incidence of excessive fluoride in groundwater is intense and alarming in the Indian states of Telangana, Bihar, Gujarat, Madhya Pradesh, Rajasthan, Tamil Nadu, Assam and Uttar Pradesh $^{30}$. In the present study area which is a part of Jamui district of Bihar state in India, where excessive fluoride concentration has been reported in groundwater in parts of Indo-Gangetic Alluvial Plains where population density is relatively high ${ }^{31}$.

The principal objective of this study is to (1) outline the geochemical mechanisms responsible for the fluoride enhancement in the aquifers of study area vis-à-vis plausible cause(s) and source characterization with the aid of field geological and petrographic parameterization of host rocks, (2) assessment of health risk from fluoride ingestion through drinking water for males, females and children (3) displaying GIS-based spatial and temporal distribution of fluoride and identification of risk areas for taking preventive measures. Therefore, the outcome of the medical geological study would be helpful in chalking out future and long-term planning for augmenting safe drinking water resources, especially in areas, where groundwater is stressed and affected by fluoride contamination with a view to consequently minimize the adverse health impacts due to excessive fluoride exposure.

\section{Geological and Hydrogeological Assessment of Study Areas}

The study area is located between North latitude $24^{\circ} 40^{\prime}$ to $25^{\circ} 10^{\prime}$ and East longitude $85^{0} 50^{\prime}$ to $86^{\circ} 35^{\prime}$ is a part of Jamui district in Bihar state, covers large tract of Indo-Gangetic Alluvial Plains. It covers about $1791 \mathrm{~km}^{2}$, with six administrative blocks: Laxhmipur, Sikandra, Khaira, Gidhour, Sono, Barhat and Jhajha. The hot weather starts in March and continues till middle of June. Generally rains commence in June and lasts till October. A tropical monsoon climate prevails in the area with an average annual rainfall of study area is nearly $1042 \mathrm{~mm}$ and most of the rainfall is received during June to September due to south-west monsoon. Catchments of Kiul River and Barnar River form a major part of the study area and the Sukhnar, Bernar and Ulai streams drain this region. The Nagi stream flows to the west and finally joins the Ulai River near Patsanda and all the streams named above, become dry during summer.

The area comprises of diverse geomorphology and major geomorphologic units are rocky upland, pediplain and alluvial plain (Fig. 1). Maximum height of $475 \mathrm{~m}$ above mean sea level has been found in Barhat block. The rolling topography of pediplain consists of relief up to $300 \mathrm{~m}$ above mean sea level. Alluvial fills in the study area is a part of Jamui Formation which constitutes the oldest continental quaternary deposits and is generally termed as "older alluvium" in Indian geology ${ }^{32}$. The thickness of the alluvium increases towards north along the river courses finally merging with the Gangetic alluvium, south of the river Ganga. Thickness of the alluvium varies from $90 \mathrm{~m}$ in northern part to $10 \mathrm{~m}$ in southern part $^{33}$. The major rock types found in this region are quartzite, quartz-mica schist, biotite-muscovite schist, hornblende schist, granite, composite gneisses, pegmatites, amphibolite and quartz veins. Exposure of biotite/muscovite-schists occurs in the narrow zone between the Barnar and Ulai streams. Massive granitic bodies are seen mostly as inselbergs. Medium grained granites are exposed as small bands/layers from $1.5 \mathrm{~km}$ west of Tarakura to $1.2 \mathrm{~km}$ SE of Korwadih. Biotite gneisses form a narrow zone from west of Bhitra to west of Lalmatia and is also seen south-east of Bhelbinda, Karhara and east of Dhamna. Medium to coarse-grained, grey to pink and composite biotite gneisses have also been encountered at some places.

The most potential aquifer in the study area is found in the valley-fill material. It consists of fine, medium as well as coarse sands. Due to humid climate, chemical weathering is also prevalent in the area. As a result, moderately thick weathered mantle has been formed due to weathering of crystalline rocks. Depth to water level is somewhat higher in the weathered zone than alluvium zone. Highly fractured crystalline rocks are also good depository/repository of groundwater in the area. CGWB drilled wells of this area confirms three to four sets of fractures/ joints occurring at different depths up to $200 \mathrm{~m}$ bgl (below ground level).

\section{Materials and Methods}

Sample collection metrics and analytical approaches. Seventy six groundwater samples were collected in May 2014 and 53 groundwater samples were collected in November 2014 from shallow and deep wells respectively, for estimation of major ions. Ninety samples were collected in both seasons (2014) for estimation of fluoride separately. Out of these, 22 samples belonged to shallow aquifer and remaining were collected from deeper aquifer. Also, resampled again in 33 random sites during May, 2018 and there is no major change in the obtained results (Supplementary Fig. S1). Groundwater samples were collected in high density polyethylene bottle (HDPE) which were rinsed twice with distilled water before collection of water samples. All the chemical parameters were estimated within two weeks after collection of samples using standard procedures as given by American Public Health Association ${ }^{34}$.

Sodium and Potassium were estimated in the groundwater samples using flame photometer (Systronics 128). Fluoride in the water samples were analysed following SPADNS [4,5-Dihydroxy-3-(p-sulfophenylazo)2,7-naphthalene disulfonic acid, trisodium salt] colorimetric method by using double beam spectrophotometer (Systronics 2202). Analysis of water samples for bicarbonate and carbonate was carried by using titrimetry method. Total hardness (TH) as $\mathrm{CaCO}_{3}$, Calcium and Magnesium were analysed using EDTA method. All 


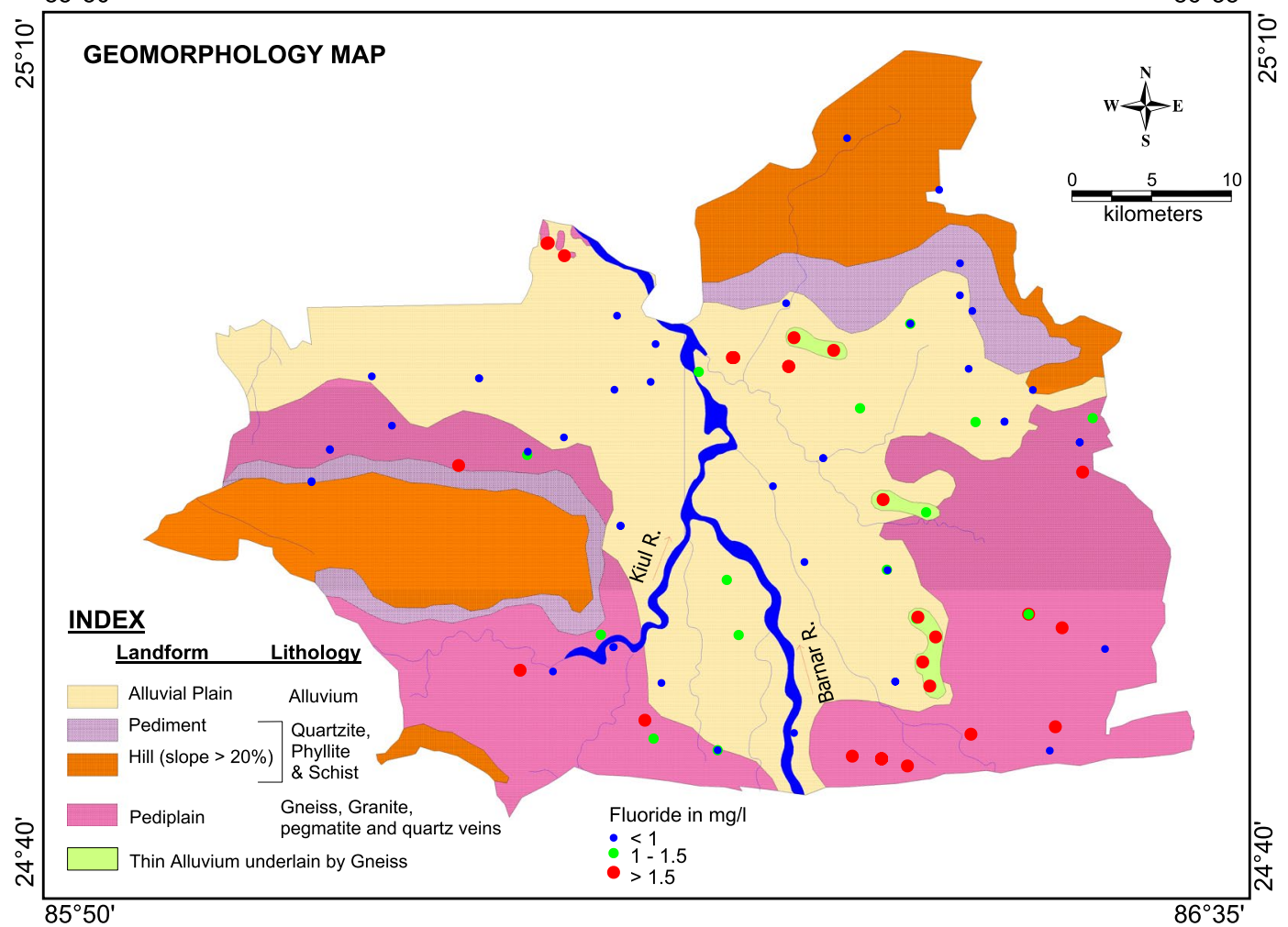

Figure 1. Map illustrating location of groundwater samples alongside geology and geomorphology of the study area.

chemical parameters, except $\mathrm{pH}$ (unit) and EC $(\mu \mathrm{s} / \mathrm{cm})$, have been expressed in terms of $\mathrm{mg} / \mathrm{L}$. The analytical precision of data was ensured by screening water samples having ionic charge balance beyond $\pm 5 \%$. The Quality control was achieved by using duplicate sub-samples and standard materials.

Fluoride hazard quotient and medical geological health implications in divergent human populace. Medical geology of the area, combining health risk assessment is an effective method to estimate the probability and content of adverse impact on human health due to exposure of a specific chemical for a specific duration ${ }^{29,35-37}$. Selinus et al. (2018) ${ }^{38}$ advocated risk assessment of human health on exposure of any chemical comprises to be of four stages. These are hazard identification, toxicity reference values selection, exposure assessment, and risk characterization. In this study, assessment of human health risk is undertaken based on exposure to fluoride and overall medical geological environment has been outlined. There are many ways of exposure to fluoride, for instance, consumption of drinking water, intake of other beverages and food, oral soil intake, inhalation of dust and ingestion of fluoride rich toothpaste, though of late this practice is discontinued ${ }^{11}$. It has been emphasized in several studies that drinking water is the prominent source of exposure to non-carcinogenic risk by fluoride ${ }^{39}$. Therefore, health risk associated with daily consumption of excess fluoride water has been calculated for the present study area by using following formula $(1)^{40}$ :

$$
\text { Chronic daily intake }(\mathrm{CDI})=[\mathrm{CW} * \mathrm{IR} * \mathrm{EF} * \mathrm{ED}] /[\mathrm{BW} * \mathrm{AT}]
$$

where CDI is chronic daily intake of water consumed per day by drinking water $(\mathrm{mg} / \mathrm{kg} / \mathrm{day}), \mathrm{C}_{\mathrm{w}}$ is the concentration of fluoride in drinking water $(\mathrm{mg} / \mathrm{L}), \mathrm{IR}$ is the drinking water ingestion rate (L/day), EF is the exposure frequency (day/year) and ED is exposure period (years), BW is average body weight (kg) and AT denotes average exposure time (days). (The standard reference values of all these components used in the assessment is furnished in Supplementary Table S1).

The non-carcinogenic risk to human health caused by exposure to fluoride is expressed in terms of hazard quotient (HQ) and is calculated using formulae (2):

$$
\text { HQFluoride }=\frac{\mathrm{CDI}}{\mathrm{RfD}}
$$

In the above formulae RfD denotes the reference fluoride dose in $\mathrm{mg} / \mathrm{kg} /$ day. RfD is used to assess the health risk of fluoride during a specific exposure pathway. According to Integrated Risk Information System (IRIS) of USEPA, the amount of Rfd through oral ingestion and drinking water is $0.06 \mathrm{mg} / \mathrm{kg} / \mathrm{day}(0.05$ water and 0.01 diet $)^{6}$. HQ value less than one ensures safety from the risk of adverse health implications, whereas, if HQ value 
exceeds unitary value, there may be potential non-carcinogenic health effects due to ingestion of fluoride contaminated water.

\section{Results and Discussion}

Role of major ion chemistry and implications on health. The statistical parameters like minimum, maximum and \% of groundwater samples below permissible limit as per BIS, $2012^{41}$ for various chemical constituents in pre and post-monsoon are presented in Supplementary Table S2.There is a noticeable difference between chemical constituent of shallow and deeper aquifer. In pre-monsoon, groundwater exceeds the maximum permissible limit of sodium concentration $(200 \mathrm{mg} / \mathrm{L})^{41}$, in $44 \%$ shallow wells and $17 \%$ deeper wells, respectively, while in post-monsoon, $13 \%$ shallow and $17 \%$ deeper wells exceed this limit of $200 \mathrm{mg} / \mathrm{L}$. In pre-monsoon $36 \%$ and in post-monsoon $30 \%$ groundwater samples exceeds magnesium concentration compared to calcium. Once calcium reaches super-saturation, it tends to precipitate resulting in excess of magnesium in the solution in comparison to calcium. The means of $\mathrm{NO}_{3}, \mathrm{Cl}$ and $\mathrm{SO}_{4}$ in shallow aquifers in pre-monsoon are $28.13 \mathrm{mg} / \mathrm{L}, 103.5 \mathrm{mg} / \mathrm{L}$ and $55.81 \mathrm{mg} / \mathrm{L}$ respectively whereas, in deep aquifers the respective values are $22.3 \mathrm{mg} / \mathrm{L}, 103.46 \mathrm{mg} / \mathrm{L}$ and $35.06 \mathrm{mg} / \mathrm{L}$. About $13 \%$ groundwater samples in pre-monsoon and $18 \%$ in post-monsoon exceed the required acceptable limit of $250 \mathrm{mg} / \mathrm{L}$ chloride ${ }^{41}$. Higher chloride values have been noticed in shallow aquifer water samples in comparison to deeper groundwater samples. High evaporation and local contaminants may have been contributing to elevated chloride concentration in shallow aquifers ${ }^{42}$.

Anthropogenic sources of pollution may be the reason for higher nitrate concentration in the shallow aquifer groundwater samples as there is no evidence of geogenic origin of nitrate in the study region ${ }^{43}$. In pre-monsoon, fluoride concentration ranges from $0.01 \mathrm{mg} / \mathrm{L}$ to $4.8 \mathrm{mg} / \mathrm{L}$ with a mean of $1.06 \mathrm{mg} / \mathrm{L}$ in shallow aquifers and from $0.01 \mathrm{mg} / \mathrm{L}$ to $5.8 \mathrm{mg} / \mathrm{L}$ with a mean of $1.38 \mathrm{mg} / \mathrm{L}$ in deep aquifers. While in post-monsoon, fluoride concentration ranges from $0.02 \mathrm{mg} / \mathrm{L}$ to $5.54 \mathrm{mg} / \mathrm{L}$ with a mean of $0.98 \mathrm{mg} / \mathrm{L}$ in shallow aquifers and from $0.01 \mathrm{mg} / \mathrm{L}$ to $5.65 \mathrm{mg} / \mathrm{L}$ with a mean of $1.23 \mathrm{mg} / \mathrm{L}$ in deeper aquifers. A total of $19 \%$ and $18 \%$ groundwater samples collected from shallow aquifers exceed the permissible limit of $1.5 \mathrm{mg} / \mathrm{L}^{41}$ in pre and post-monsoon respectively. In deep aquifer, $34 \%$ and $28 \%$ groundwater samples are beyond the permissible limit of $1.5 \mathrm{mg} / \mathrm{L}$ before and after precipitation, respectively. Therefore, consumption of groundwater from respective sites where $\mathrm{Na}, \mathrm{K}, \mathrm{NO}_{3}$ and $\mathrm{F}$ exceeded the permissible limits may cause hypertensive effects, bitter taste, methaemoglobinaemia, skeletal and dental fluorosis respectively.

Classification and genesis of groundwater vis-a-vis contamination. The prevailing dominant groundwater facies in the study area has been identified based on the content (meq/l) of selective dominant anions $\left(\mathrm{Cl}^{-}\right.$and $\left.\mathrm{SO}_{4}^{2-}\right)$ and a cation $\left(\mathrm{Na}^{+}\right)$after referring to the Soltan ${ }^{44}$ base- exchange indices. Here the groundwater classification has been made using the following Eq. 3, where all units are in meq/L.

$$
\mathrm{r}_{1}=\mathrm{Na}^{+}-\mathrm{Cl}^{-} / \mathrm{SO}_{4}^{2-}
$$

In the above mentioned equation, $\mathrm{r}_{1}$ value more than unitary $(>1)$ signifies groundwater is $\mathrm{Na}^{+}-\mathrm{HCO}_{3}{ }^{-}$type, on the contrary, $\mathrm{r}_{1}$ value less than unitary $(<1)$ denotes that groundwater is representing $\mathrm{Na}^{+}-\mathrm{SO}_{4}{ }^{2-}$ type. It is clear from the base exchange index $\left(r_{1}\right)$ plot (Fig. 2a) that most of the samples belong to $\mathrm{Na}^{+}-\mathrm{HCO}_{3}{ }^{-}$type while $28 \%$ sample in post-monsoon and $23 \%$ sample in pre-monsoon belong to $\mathrm{Na}^{+}-\mathrm{SO}_{4}{ }^{2-}$ type. It is well established that the $\mathrm{Na}-\mathrm{HCO}_{3}$ type water accelerates the precipitation of calcite, accompanying the release of fluoride from minerals in gneissic basement rocks and granitic intrusive due to dissolution of silicates and consequently enhancing fluoride concentration in groundwater ${ }^{30,45,46}$. The mineral reaction followed by ion-exchange reactions are the key governing factors responsible for elevated fluoride concentration reported in the study area ${ }^{39}$ :

$$
\begin{gathered}
\mathrm{CaF}_{2}+\mathrm{Na}_{2} \mathrm{CO}_{3} \leftrightarrow \mathrm{CaCO}_{3}+2 \mathrm{~F}^{-}+2 \mathrm{Na}^{+} \\
\mathrm{CaF}_{2}+2 \mathrm{NaHCO}_{3} \rightarrow \mathrm{CaCO}_{3(a q)}+2 \mathrm{Na}^{+}+2 \mathrm{~F}^{-}+\mathrm{H}_{2} \mathrm{O}+\mathrm{CO}_{2}
\end{gathered}
$$

In general, dynamic groundwater resource gets replenished each year depending on hydrogeological and meteorological conditions. In the present study, meteoric genesis index $\left(r_{2}\right)$ as suggested by Soltan ${ }^{44}$ is used for the detection of source of groundwater (Eq. 4).

$$
\mathrm{r}_{2}=\left(\mathrm{K}^{+}+\mathrm{Na}^{+}\right)-\mathrm{Cl}^{-} / \mathrm{SO}_{4}^{2-}
$$

According to this index, $\mathrm{r}_{2}$ value less than one $(<1)$ indicates groundwater belongs to deeper meteoric percolation while $r_{2}$ value more than one $(>1)$ denotes shallow meteoric percolation. As is evident from Fig. 2b, majority of the samples in both seasons are dominated by shallow meteoric percolation (i.e. $89 \%$ groundwater samples in pre-monsoon and $87 \%$ groundwater samples in post-monsoon). It may be concluded from this that addition of fluoride in the solution is due to its prolonged retention time in the aquifer matrix and not from meteoric sources $^{31}$. It has also been endorsed in some more studies that fluoride concentration generally banks on the extent of water- rock interaction as fluoride primarily originates from geogenic sources ${ }^{5,45,47}$.

Spatio-temporal and depth-wise distribution of fluoride. In the shallow aquifer $23 \%$ water samples and in deep aquifers $34 \%$ water samples have fluoride concentration more than the maximum permissible limit of $1.5 \mathrm{mg} / \mathrm{L}$ (Supplementary Fig. S2a and $2 \mathrm{~b}$ ). It is found that groundwater samples from hard rock areas are more enriched in fluoride concentration than groundwater samples from alluvial areas. For comparing fluoride concentration in deeper and shallow wells, some groundwater samples were collected from paired deep and shallow aquifers of same location. It is observed that in paired samples of hard rock areas, both shallow as 

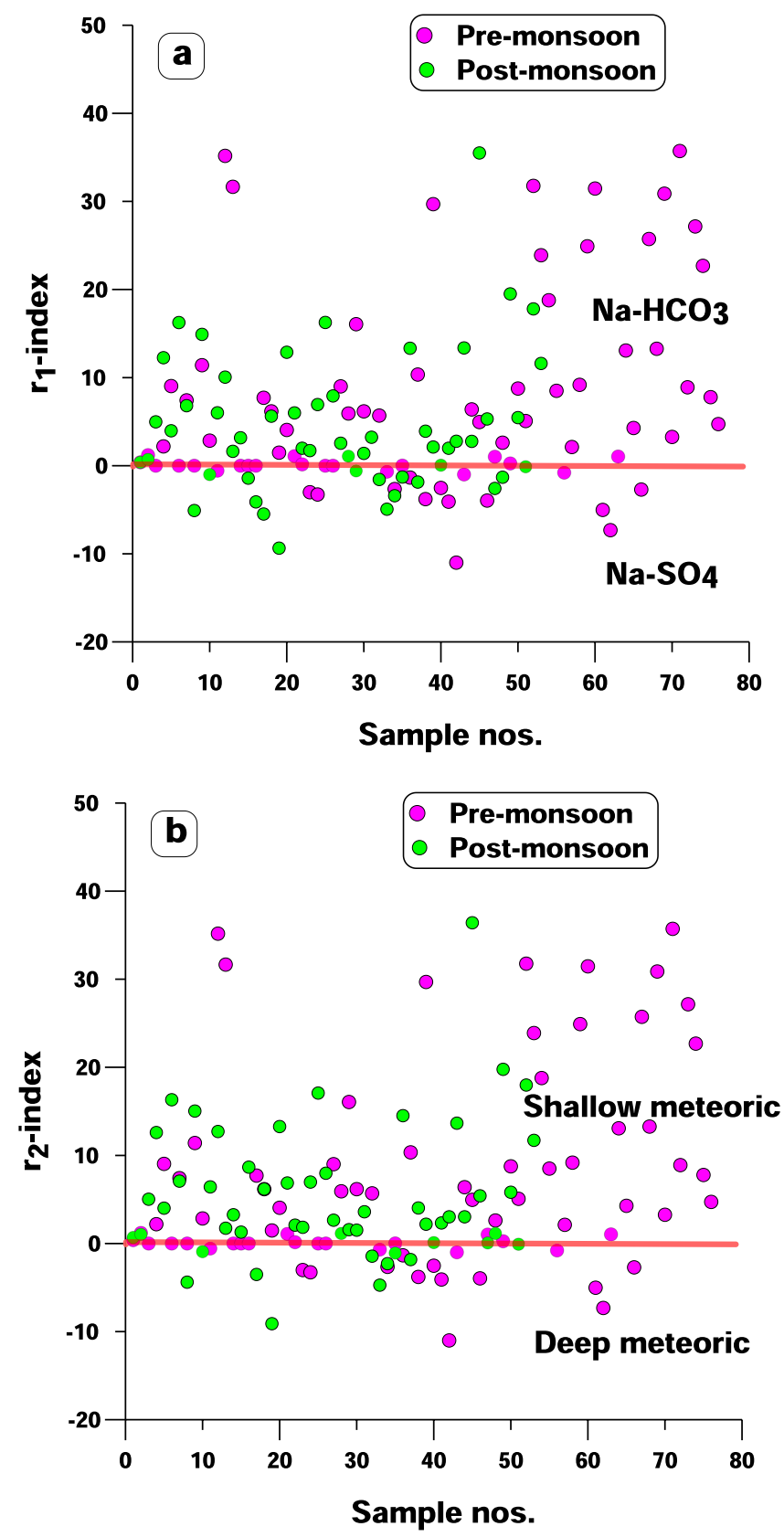

Figure 2. (a) Base exchange index $\left(\mathrm{r}_{1}\right)$ plot $(\mathbf{b})$ Meteoric genesis index $\left(\mathrm{r}_{2}\right)$ plot.

well as deeper aquifers are enriched with fluoride in solution (Fig. 3). It has been noticed that areas with high concentration of fluoride in deeper wells are also paired with high concentration of fluoride in shallow wells. Occurrence of high fluoride levels in shallow wells may be attributed to weathering of fluoride bearing material from granite, granite-gneiss, amphibolite and mica-schist and deposition of same over the host rock as a weathered mantle might be the prominent reason for higher fluoride concentration in the area ${ }^{39,47}$. Upward movement of fluoride-concentrated water from deep aquifer may be another dominant factor for enrichment of fluoride concentration in shallow wells ${ }^{48-50}$.

Spatial distribution of fluoride concentration in pre and post monsoon has been shown in Fig. 4a,b, which reveals that concentration of fluoride in the study area is not uniform and this could be plausible due to the control of typical hydrogeological conditions of the study area and water-rock interaction span (i.e., residence time). In general, elevated fluoride concentration is more common in eastern part of the area compared to western part. The fluoride-enriched pockets are mostly associated with alluvium tracks underlain by granite genesis and pediplain of gneissic intrusive rocks. In terms of seasonal variability of fluoride content, pre-monsoon has dominant concentration than post-monsoon and would be the striking observation mainly because of dilution effect due to ample rainfall. 


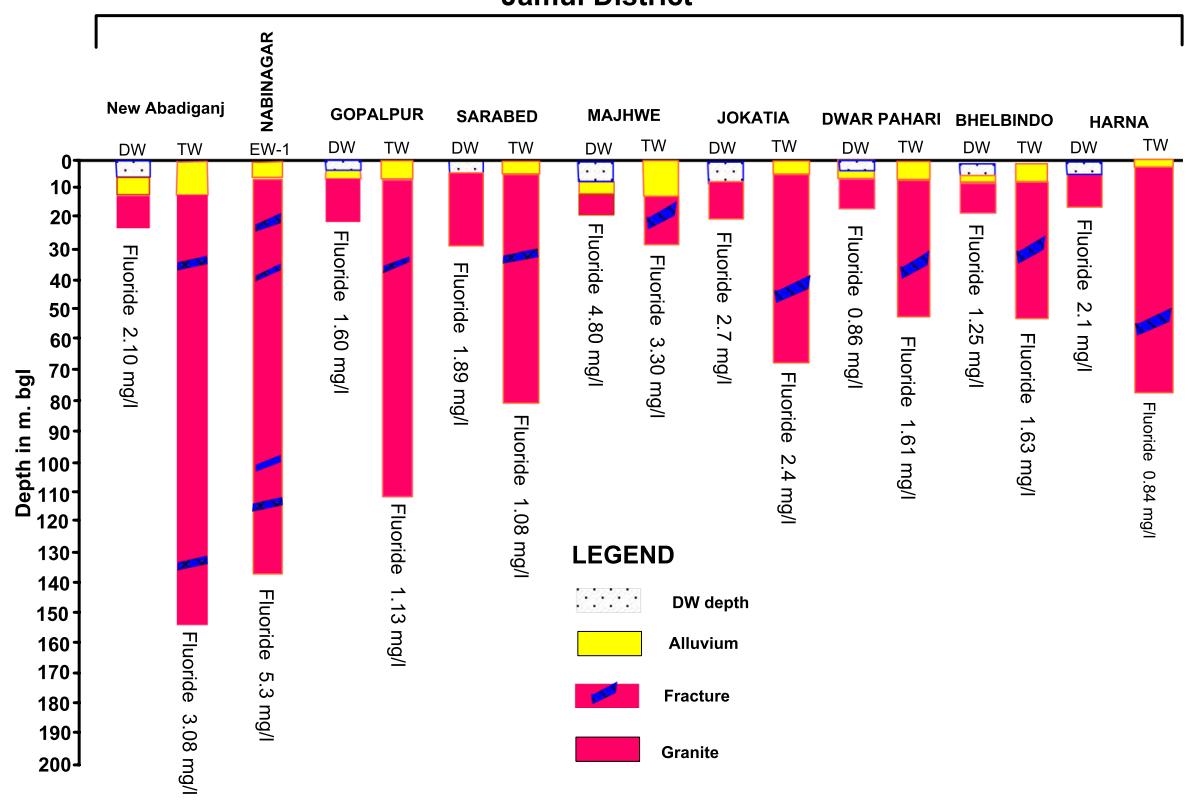

Figure 3. Fluoride distribution in paired deep and shallow wells of same location.

Petrographic fluoride indicator minerals and governing hydro-chemical mechanisms. In the study area, except for the valley-filled materials along the river course and fresh rock exposures over the hill ranges, entire area is occupied by moderately thick weathered mantle, developed due to in-situ weathering of crystalline rocks (Fig. 1). Therefore, to establish the possible source of fluoride and its fixation into groundwater, the rock samples were collected from the study area and minerals have been characterized using detailed petrographic studies. Microscopic observation indicates the presence of K-feldspar, plagioclase feldspar, amphibole and biotite in the rock samples collected from Majhwe village (Fig. 5). The fluorine-bearing minerals viz., apatite and sphene have also been observed within the above lithopackage exhibiting different scales of alteration/ decomposition. Fe leachates are seen along biotite rich zones and along grain boundaries of feldspar from the samples collected from Panch Pahari area (Fig. 5).

It is clear from the microscopic study that high-fluorine minerals such as amphibole, biotite and apatite (as well as sphene) contribute fluoride to percolating groundwater/ within the aquifer that triggers to high fluoride anomalies in groundwater in areas of high abundance of these minerals. Some of the in-situ reactions under alkaline conditions causing dissolution of fluorine bearing minerals namely fluorite, apatite, biotite and hornblende which are responsible for the higher fluoride concentration in the area are as follows ${ }^{46,51}$ :

Fluorite (Eq. 7)

$$
\mathrm{CaF}_{2}+2 \mathrm{HCO}_{3} \rightarrow \mathrm{CaCO}_{3}+2 \mathrm{~F}^{-}+\mathrm{H}_{2} \mathrm{O}+\mathrm{CO}_{2}
$$

Biotite (Eq. 8)

$$
\mathrm{KMg}_{3}\left[\mathrm{AlSi}_{3} \mathrm{O}_{10}\right] \mathrm{F}_{2}+2 \mathrm{OH}^{-} \rightarrow \mathrm{KMg}\left[\mathrm{AlSi}_{3} \mathrm{O}_{10}\right][\mathrm{OH}]_{2}+2 \mathrm{~F}^{-}
$$

Hornblende (Eq. 9)

$$
\mathrm{Ca}_{5} \mathrm{Mg}_{5}\left[\begin{array}{lll}
\mathrm{Si}_{6} & \mathrm{Al}_{2} & \mathrm{O}_{22}
\end{array}\right] \mathrm{F}_{2}+2 \mathrm{OH}^{-} \rightarrow \mathrm{Ca}_{5} \mathrm{Mg}_{5}\left[\mathrm{Si}_{6} \mathrm{Al}_{2} \mathrm{O}_{22}\right][\mathrm{OH}]_{2}+2 F^{-}
$$

Apatite (Eq. 10)

$$
\mathrm{Ca}_{10}\left(\mathrm{PO}_{4}\right)_{6} \mathrm{~F}_{2}+2 \mathrm{OH}^{-} \rightarrow \mathrm{Ca}_{10}\left(\mathrm{PO}_{4}\right)_{6} \mathrm{OH}_{2}+2 \mathrm{~F}^{-}
$$

Muscovite (Eq. 11)

$$
\mathrm{KAl}_{2}\left[\mathrm{AlSi}_{3} \mathrm{O}_{10}\right] \mathrm{F}_{2}+2 \mathrm{OH}^{-} \rightarrow \mathrm{KAl}_{2}\left[\mathrm{AlSi}_{3} \mathrm{O}_{10}\right] \mathrm{F}_{2}+2 \mathrm{OH}
$$

Furthermore, many of the researchers across the world suggested that weathering of fluoride-bearing minerals such as apatite, biotite, mica, sphene, hornblende and various other minerals liberate fluoride into groundwater under favorable conditions (Eqs 7-11) ${ }^{46,51}$. Amongst all, amphibole group is least resistant to weathering and thus probably may add higher amounts of fluoride to groundwater aquifer ${ }^{52}$. Generally, biotite in granite rocks may possess as much as $0.91 \%$ fluorine, hornblende $(0.71 \%)$ and fluorapatite $(3.72 \%)^{53}$. In a batch dissolution study 

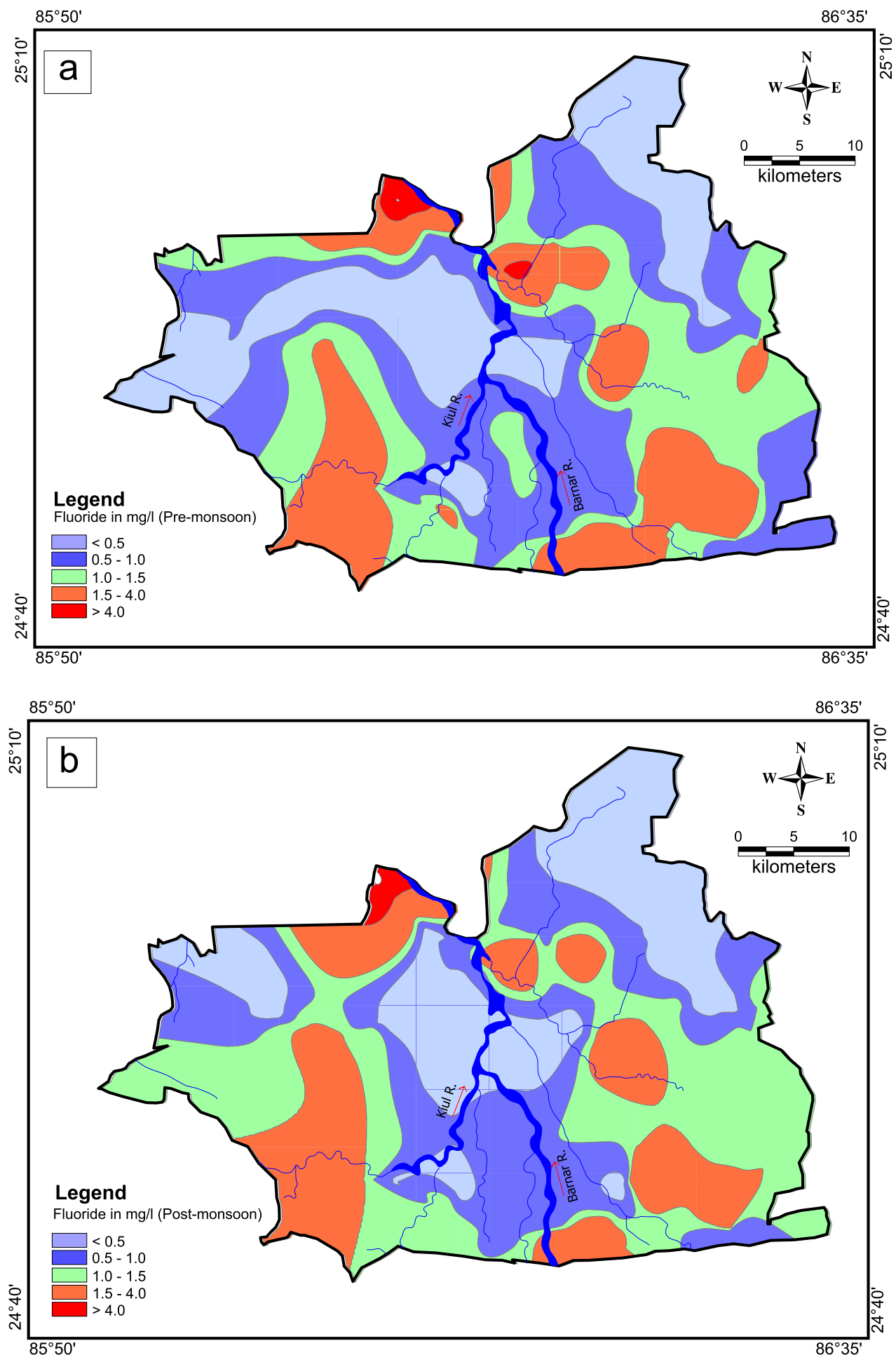

Figure 4. (a) Spatial distribution of fluoride in pre-monsoon (b) Spatial distribution of fluoride in postmonsoon.

performed in the laboratory by Chae et al.,(2006) established that at room temperature $\left(25^{\circ} \mathrm{C}\right)$, dissolution of biotite enhances fluoride concentration by $100 \%$ within 200 hours $^{54}$.

Additionally, humid climate in the study area also enhances the weathering of host rocks and as a result of which, weathered material has developed over granite, granite-gneiss, amphibolite and mica-schist. Fluorine $\left(\mathrm{F}^{-}\right)$ being negatively charged ion and member of the halogen group, is commonly found in such weathered material and will possibly contribute to the groundwater by rock-water interaction mechanism under favorable $\mathrm{pH}$ conditions, due to process of selective sorption of $\mathrm{OH}^{-}$to the aquifer matrix, and eventually $\mathrm{F}^{-}$gets released into the solution (Eq. 12). 

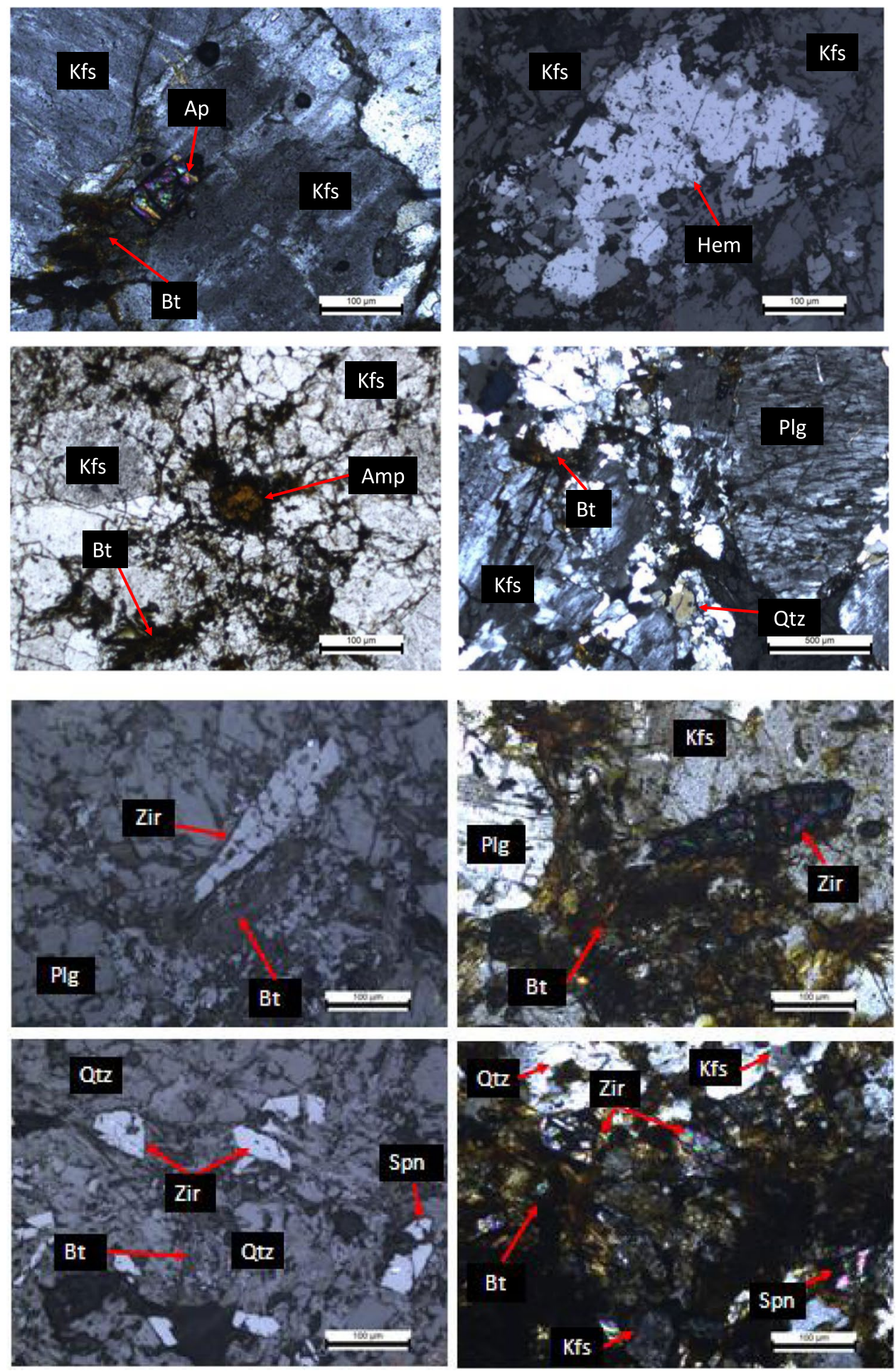

Figure 5. Microscopic observation of rock specimens illustrating different mineral assemblages: Spn-sphene, Ap-apatite, Bt-biotite, Amp-Amphibole, Qtz-quartz, Kfs-potassium feldspar, Zir-zircon.

$$
\mathrm{R}-\mathrm{F}+\mathrm{HOH} \rightarrow \mathrm{R}-\mathrm{OH}+\mathrm{HF}
$$

This sort of substitution readily takes place in the aquifer matrix mainly due to the ionic radius of fluoride $(133 \mathrm{pm})$ nearly resembles with that of hydroxyl ion $(140 \mathrm{pm})^{55,56}$. Say for an instance, if the hydrogen ion concentration of less than 7 prevails in the groundwater, $\mathrm{F}^{-}$remains adhered with clay due to the low solubility of $\mathrm{F}^{-}$. The reverse is the situation in alkaline medium, where, $\mathrm{OH}^{-}$group replaces the exchangeable $\mathrm{F}^{-}$of clay minerals (biotite/muscovite) resulting in the enhanced $\mathrm{F}^{-}$concentration in aquifer ${ }^{48,57}$. 

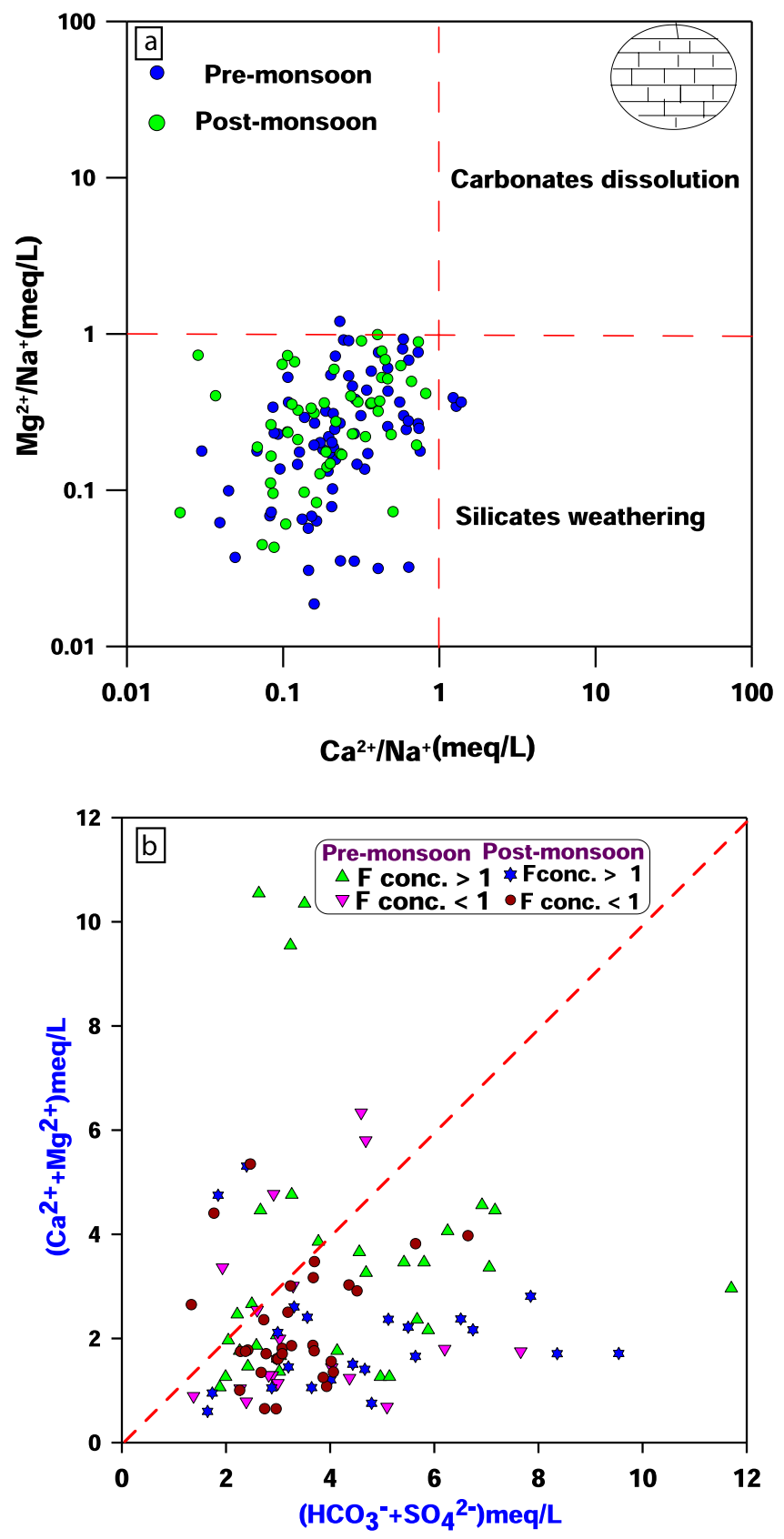

Figure 6. (a) Bivariant plot of $\mathrm{Mg}^{2+} / \mathrm{Na}^{+}$verses $\mathrm{Ca}^{2+} / \mathrm{Na}^{+}$and (b) Cross plot of $\left(\mathrm{Ca}^{2+}+\mathrm{Mg}^{2+}\right)$ verses $\left(\mathrm{HCO}_{3}{ }^{-}+\mathrm{SO}_{4}{ }^{2-}\right)$.

Furthermore, bivariant plot of $\mathrm{Mg}^{2+} / \mathrm{Na}^{+}$verses $\mathrm{Ca}^{2+} / \mathrm{Na}^{+}$(Fig. 6a) clearly exhibits that silicate weathering (granite gneiss) is the dominant process contributing to the chemical quality in the groundwater of the area. Again, observing the cross plot of $\left(\mathrm{Ca}^{2+}+\mathrm{Mg}^{2+}\right)$ verses $\left(\mathrm{HCO}_{3}{ }^{-}+\mathrm{SO}_{4}{ }^{2-}\right)$ (Fig. 6b) implies that most of the samples having fluoride concentration more than one in both seasons are placed below equilline, which further confirms silicate weathering and ion exchange in the area is responsible for higher concentrations of $\mathrm{F}^{-}$and $\mathrm{HCO}_{3}{ }^{-}$in the solution ${ }^{31,46,58}$. It is a well-established fact that, increase in $\mathrm{pH}$ (i.e. alkaline condition), sodium and bicarbonate ion concentration ultimately increases concentration of fluoride in the groundwater due to aforementioned reactions and mechanisms.

In essence, rock-water interaction due to longer residence time and ion exchange process accommodates weathering and leaching of fluoride-bearing minerals in rock formations under alkaline environment thereby adding higher amounts of fluoride to groundwater/ aquifer. This observation is in agreement with the results obtained by others as well ${ }^{30,31,39}$.

Excess fluoride exposure and health related implications on inhabitants. Health risk assessment is of great importance for estimation of nature and probability of health effect to the inhabitants residing in the 

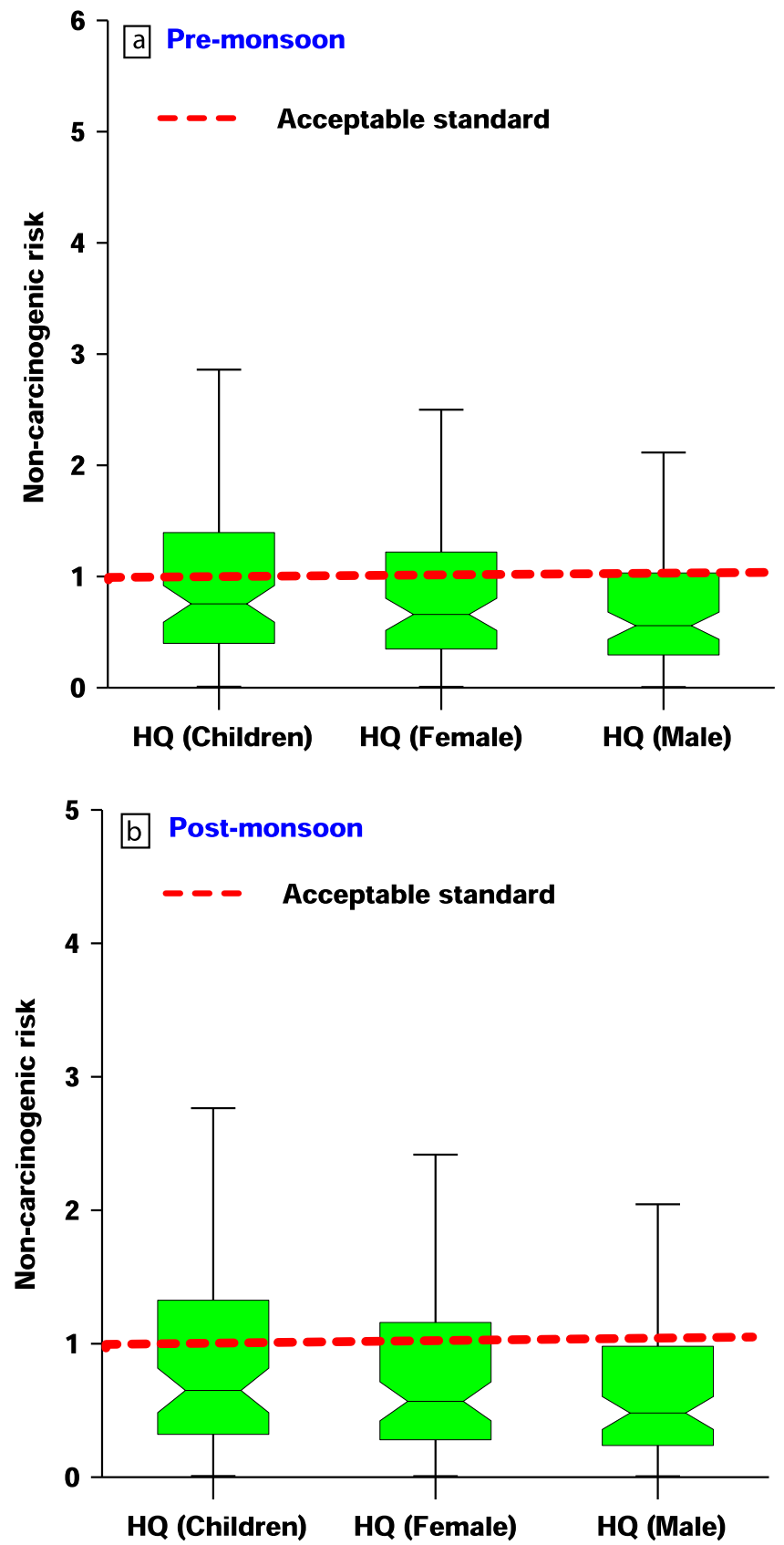

Figure 7. Boxplots showing the result of non-carcinogenic risk for fluoride in (a) pre-monsoon and (b) postmonsoon.

areas, which are prone to health hazard contaminants through the drinking water. Amongst all contaminants, oral intake of excess fluoride through drinking water has vital role and may pose non-carcinogenic health risk to population $^{41}$. Accordingly, non-carcinogenic risk of fluoride to human health is estimated in terms of hazard quotient (HQ) and the results of health risk assessment for different age groups is shown in (Fig. 7a,b) and Table 1. Hazard quotient for fluoride in pre and post monsoon season were $0.009-5.02$ and $0.009-4.80$ with a mean value of 1.13 and 1.01 for children, $0.008-4.39$ and $0.008-4.19$ with a mean value of 0.98 and 0.88 for female and $0.006-3.71$ and $0.006-3.55$ with a mean value of 0.83 and 0.75 for males respectively. Children consumers in the study area are more prone to non-carcinogenic risk of fluoride exposure as $32 \%$ shallow well and $44 \%$ deeper well exhibit HQ value for fluoride more than one in water samples collected before precipitation. During post-monsoon, also, $27 \%$ shallow wells and $40 \%$ deeper wells have HQ value of fluoride more than one for children. As shown in Fig. 7(a,b), the HQ values for fluoride are in the order of children $>$ females $>$ males for both the seasons. It has been established in various researches that children age group is more prone to non-carcinogenic risk of fluoride as compared to adults ${ }^{59-61}$. Lower body weight of children than adults may be the reason behind higher risk for children ${ }^{62}$. Fluoride exposure in early stages of life is very important as it may prevent caries but may develop dental and skeletal fluorosis. Fluoride intake during first three years of life is most critical in fluorosis etiology ${ }^{63}$. 


\begin{tabular}{|c|c|c|c|c|c|c|}
\hline Humans & $\begin{array}{l}\text { Type of } \\
\text { well }\end{array}$ & $\begin{array}{l}\text { Hazard } \\
\text { quotient } \\
\text { (HQ) }\end{array}$ & Health risk & $\begin{array}{l}\text { Number of } \\
\text { samples }\end{array}$ & $\begin{array}{l}\text { Percentage of } \\
\text { samples (Pre- } \\
\text { monsoon) }\end{array}$ & $\begin{array}{l}\text { Percentage of } \\
\text { samples (post- } \\
\text { monsoon) }\end{array}$ \\
\hline \multirow{4}{*}{ Males } & \multirow{2}{*}{ Shallow } & $<1$ & No risk & 22 & $73 \%$ & $82 \%$ \\
\hline & & $>1$ & High risk & 22 & $27 \%$ & $18 \%$ \\
\hline & \multirow{2}{*}{ Deep } & $<1$ & No risk & 68 & $67 \%$ & $74 \%$ \\
\hline & & $>1$ & High risk & 68 & $33 \%$ & $26 \%$ \\
\hline \multirow{4}{*}{ Females } & \multirow{2}{*}{ Shallow } & $<1$ & No risk & 22 & $73 \%$ & $77 \%$ \\
\hline & & $>1$ & High risk & 22 & $27 \%$ & $23 \%$ \\
\hline & \multirow{2}{*}{ Deep } & $<1$ & No risk & 68 & $62 \%$ & $64 \%$ \\
\hline & & $>1$ & High risk & 68 & $38 \%$ & $36 \%$ \\
\hline \multirow{4}{*}{ Children } & \multirow{2}{*}{ Shallow } & $<1$ & No risk & 22 & $68 \%$ & $73 \%$ \\
\hline & & $>1$ & High risk & 22 & $32 \%$ & $27 \%$ \\
\hline & \multirow{2}{*}{ Deep } & $<1$ & No risk & 68 & $56 \%$ & $60 \%$ \\
\hline & & $>1$ & High risk & 68 & $44 \%$ & $40 \%$ \\
\hline
\end{tabular}

Table 1. Non-carcinogenic risk assessment for children, adult females, and males, in the study region due to excessive fluoride ingestion.

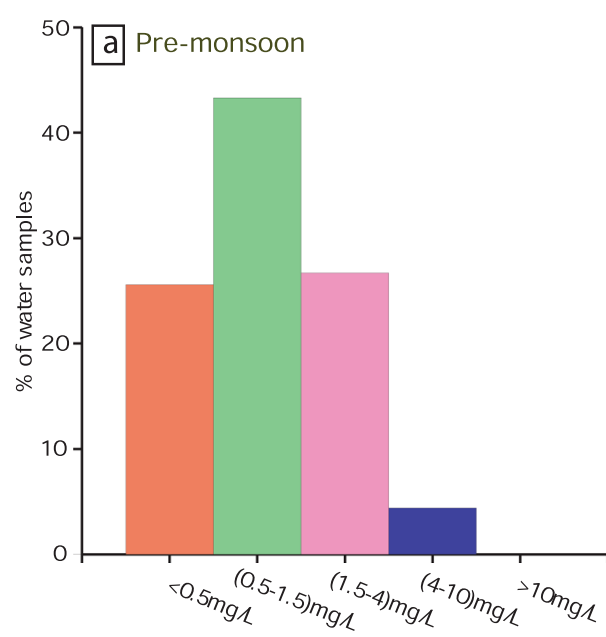

F conc. in $\mathrm{mg} / \mathrm{L}$

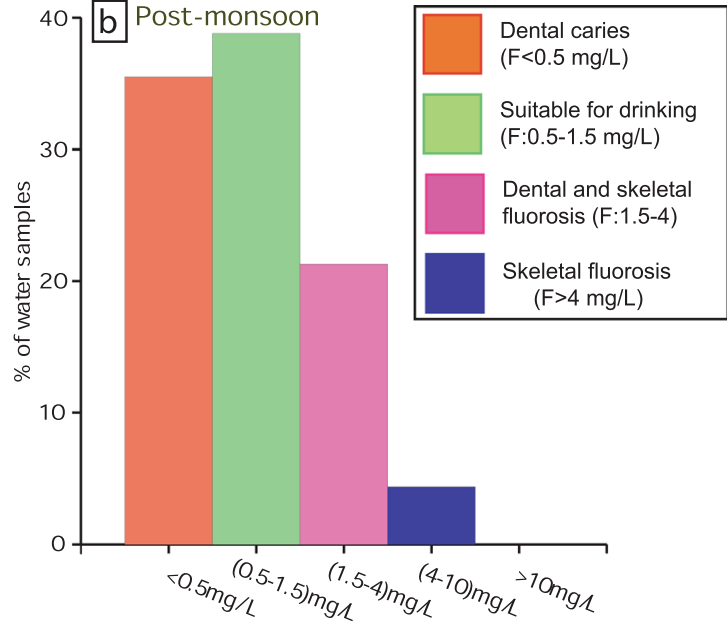

F conc. in $\mathrm{mg} / \mathrm{L}$

Figure 8. Health risk effects associated with $\mathrm{F}^{-}$ingestion in individuals during different seasons in the study area.

Consumption of drinking water with fluoride concentration more than the prescribed limit of $1.5 \mathrm{mg} / \mathrm{L}$ in both seasons may develop dental fluorosis in children and adults. On the basis of fluoride concentration (mg/L), groundwater of the study area has been divided into five classes. A total of $43 \%$ and $38 \%$ groundwater samples fall in Class-II and can be considered safe for drinking purpose. Whereas, $30 \%$ sample in pre-monsoon and $25 \%$ groundwater samples in post-monsoon falls under class-III and class-IV and may develop dental and skeletal fluorosis in consumers ${ }^{64}$ (Fig. 8a,b).

The spatial distribution of HQ for different age groups in the pre and post monsoon has been shown in Fig. 9(a-f). Scenario is worst in villages of Jhajha block, which is situated in south eastern part of the study area. In Jhajha block, 63\% and 68\% samples exhibit HQ value of fluoride for children consumers more than unitary in pre and post monsoon respectively. HQ value of fluoride for females is more than one in $58 \%$ and $64 \%$ of water samples in pre and post monsoon respectively. Fluoride concentration of more than $1.5 \mathrm{mg} / \mathrm{L}$ has been found in deeper as well as shallow aquifer in the groundwater of Jhajha block (Fig. 3) mainly because of geology (i.e. most of the part is covered by granite, gneisse and pegmatite veins) and geomorphology of the block that eventually leads to elevated HQ values in this block. In Jakotia, Loha, New Abadiganj, Lakraha, Gopalpur, Harna and Bhadwaria villages of Jhajha block, skeletal and dental fluorosis has been noticed on large scale in children and adults. Similarly, in Jamui block most of the area comprises of alluvium formation, except Majhwe village which is situated in extreme north and is surrounded by granite hillocks from three sides. In Majhwe village, HQ value for fluoride is 2.86 to 4.80 . In the groundwater samples collected from the paired wells of this village, fluoride concentration was found $4.80 \mathrm{mg} / \mathrm{L}$ and $3.60 \mathrm{mg} / \mathrm{L}$ for shallow and deeper aquifers respectively (Fig. 3). A field survey conducted in fluoride affected villages of Jhajha and Jamui blocks reveal that habitants exposed to mild dosage of fluoride contaminated water for lesser time cause discoloration of teeth with white or yellow patches in the area, 

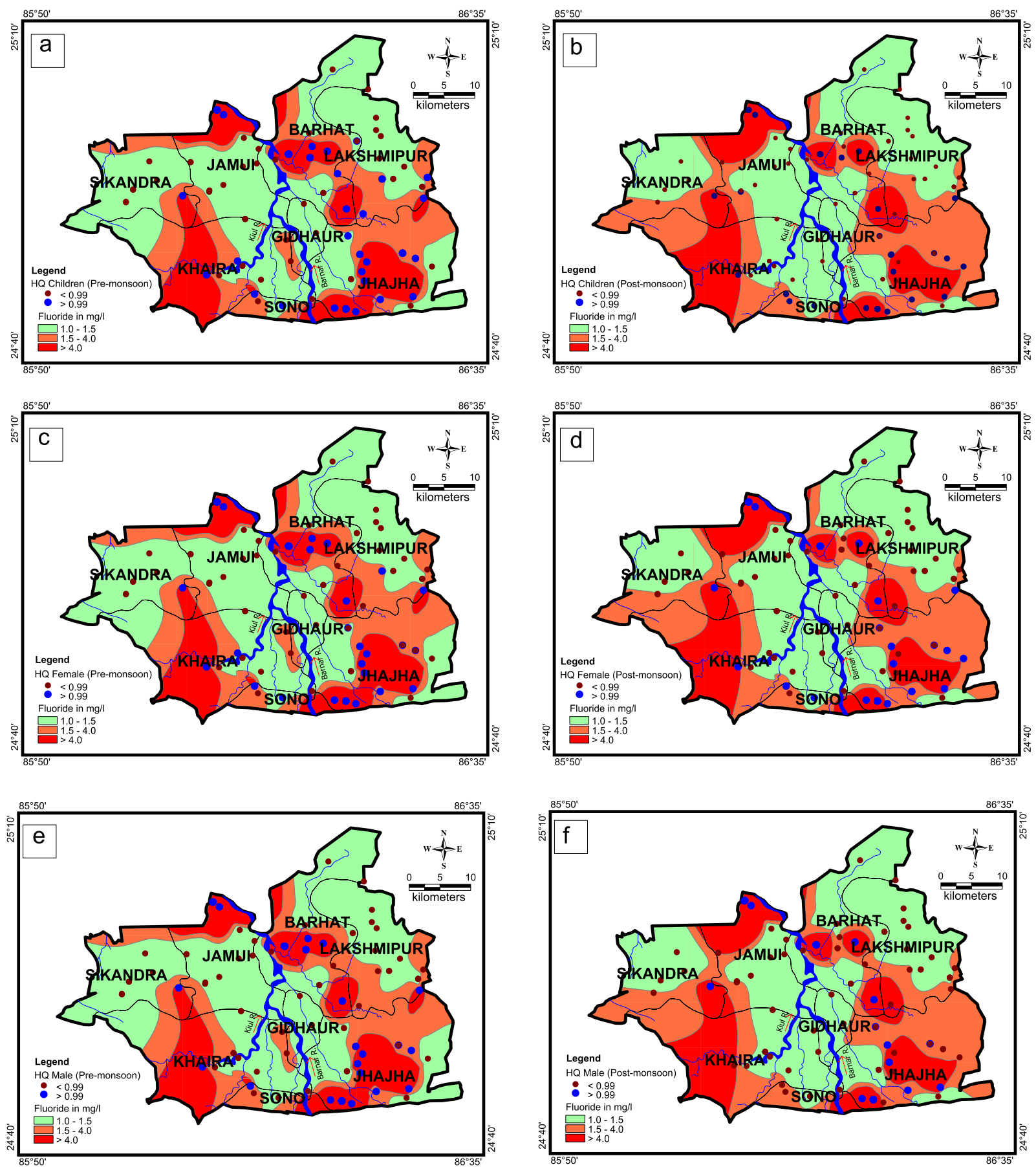

Figure 9. Spatial-temporal distribution of $\mathrm{HQ}$ along with $\mathrm{F}^{-}$during pre-monsoon (a) HQ Children, (b) HQ Female, (c) HQ Male and post-monsoon season (d) HQ Children, (e) HQ Female, (f) HQ Male.

whereas, consumption of excessive fluoride content water for the prolonged duration triggers to bone deformities or else known as skeletal fluorosis.

Northern part of the Laxhmipur block which is situated in north eastern part of the study area is covered with quartzite, phyllites and alluvium formation, has been found with lesser concentration of fluoride in groundwater. On the other hand, southern part of the Laxhmipur block in the proximity of granite gneiss terrain of Jhajha block is the area of elevated fluoride concentration vis-a-vis higher HQ values $(>1)$. In the alluvium formation of Khaira and Sikandra block, fluoride concentration is high neither in shallow nor in deep aquifer, except in the well near granite gneiss in the proximity of Gidheswar hills.

Non-carcinogenic vs. carcinogenic fluoride issue debate. In general, minerals play essential roles in the normal metabolism and physiological functions of animals and humans. Amongst, fluorine, occurring in groundwater as the fluoride $\left(\mathrm{F}^{-}\right)$ion is essential in small quantities for structural functions in bone and 
membranes $(0.5-1.0 \mathrm{mg} / \mathrm{L})^{31,65}$. Despite its usefulness, chronic ingestion of excessive $\mathrm{F}^{-}$water can cause fluorosis of the enamel and bone (i.e. $1.5-4 \mathrm{mg} / \mathrm{L}$ ) and in extreme cases, skeletal fluorosis associated with joint stiffness, calcification of ligaments, and some osteosclerosis of the pelvis and vertebrae (i.e. $4-10 \mathrm{mg} / \mathrm{L})^{3,4,66}$. This happens mainly because of the $\mathrm{F}^{-}$being highly electronegative and having similar ionic radius (133 pm) with that of hydroxyl ion $(140 \mathrm{pm})$ that leads to the formation of hydrogen fluoride ${ }^{48,55-57}$. Particularly, this compound in human body freely diffuses across the intestine, dissolves in the blood, and accumulation in calcified tissues ${ }^{7,21}$. Therefore, health related issues in and around fluoride affected areas are mostly non-carcinogenic in nature, especially from the studied areas, when fluoride in drinking water ranges not more than $10 \mathrm{mg} / \mathrm{L}^{67,68}$. However, higher doses $\left(>10 \mathrm{mg} / \mathrm{L}\right.$ ) have also been linked to crippling fluorosis and carcinogenic potential ${ }^{66-69}$ although it is not established completely $12,70,71$. Kharab et al. $(2012)^{24}$ in their study suggested some possible link with fluoride in drinking water to osteosarcoma. The limited studies on this aspect suggest that fluoride could cause cells to grow faster so that they may become cancerous in course of time, albeit debatable as no credible link exists to suggest the linkage between fluoride and effect of carcinogenicity ${ }^{23,25}$. As defined by the National Institute of Cancer (NIC) of USA, the osteosarcoma is linked to the bone cancer affecting large bones of arms and legs and it is prevalent in younger generation especially more in males to females (https://www.cancer.gov/publications/dictionaries/cancer-terms/def/osteosarcoma $)^{72}$. However, the theory is yet to be established and is still of considerable debate today. Whereas, non-carcinogenic related health effects are very much prevalent across the world and in particular in the studied areas, starts from dental to skeletal fluorosis related problems affecting more children followed by adult females as compared to adult males ${ }^{73-75}$.

Concluding remarks and possible remedial thoughts. In the study area, most of the groundwater samples from hard rock formations possess fluoride concentration more than the permissible limit of $1.5 \mathrm{mg} / \mathrm{L}$. On the other hand, groundwater samples from alluvial formations have less incidence of fluoride concentration of more than the permissible limit. Microscopic analysis of rock samples in the study area confirms the presence of fluoride-bearing minerals, for instance, biotite, apatite, quartz, sphene and hornblende. Weathering of these fluoride bearing minerals developed over granite, granite-gneiss, amphibolite and mica-schist is the prominent factor contributing to higher fluoride concentration in the study area. $\mathrm{Mg}^{2+} / \mathrm{Na}^{+}$versus $\mathrm{Ca}^{2+} / \mathrm{Na}^{+}$and $\left(\mathrm{Ca}^{2+}+\mathrm{Mg}^{2+}\right)$ verses $\left(\mathrm{HCO}_{3}{ }^{-}+\mathrm{SO}_{4}{ }^{2-}\right)$ plot further confirms that silicate weathering and ion-exchange are the dominant processes involved for the higher concentration of fluoride and bicarbonate ions in the area. The non-carcinogenic health risk assessment (HQ) reveals that children are more prone to the risk of fluoride exposure followed by females and males.

The investigation of fluoride concentration indicates that about $30 \%$ groundwater samples in pre-monsoon and $25 \%$ groundwater samples in post-monsoon fall under class-III and class-IV and, as a consequence, may develop dental and skeletal fluorosis in consumers. Symptoms of dental and skeletal fluorosis have been reported in majority of habitantsfrom the entire Jhajha block, northern part of the Lakshmipur block and Sono blocks situated in the south eastern part of the study area, where HQ exceeds the unitary value alongside F concentration $>1.5 \mathrm{mg} / \mathrm{L}$. Symptoms of dental and skeletal fluorosis have also been found in the population of Majhwe and Navinagar villages of Jamui block, situated in the north-western parts of the study area. Except Majhwe and Navinagar villages which are surrounded by granite hills from three sides, the remaining areas of Jamui block are the part of alluvium formation. However, in the groundwater resources of Krishi Kendra, Khadigram of Barhat block, fluoride concentration was within the permissible limit of $1.5 \mathrm{mg} / \mathrm{L}$, although this area is surrounded by fluoride-affected habitations. Five ponds situated in the premises of Krishi Vigyan Kendra might have been helpful in diluting the enhanced fluoride concentration. Therefore, revival of ponds and rainwater harvesting structures in the affected area may improve the quality of potable water by diluting the fluoride concentrations in the groundwater resources. Fortunately, there are large surface water reservoirs like Nakti Dam, Nagi Dam and, Belatand Dams in the study area which have a fluoride concentration within the permissible limit of $1.5 \mathrm{mg} / \mathrm{L}$. Drinking water may be supplied from these surface water reservoirs to affected habitations so that adverse health effects can be prevented. Further, it is also recommended that policymakers ought to adopt solar energy-based electrolytic de-fluoridation technology in these fluoride affected villages and regular monitoring of supplying drinking water quality apart from that of habitants health condition/implications.

Received: 18 April 2019; Accepted: 23 October 2019;

Published online: 07 November 2019

\section{References}

1. Gao, H., Jin, Y. \& Wei, J. Health risk assessment of fluoride in drinking water from Anhui Province in China. Environ. Monit. Assess. 185, 3687-3695, https://doi.org/10.1007/s10661-012-2820-9 (2013).

2. Harrison, P. T. C. Fluoride in water a UK perspective. Journal of Fluorine Chemistry 126, 1448-1456 (2005)

3. Liang, S. et al. Sodium fluoride exposure exerts toxic effects on porcine oocyte maturation. Scientific Reports 7, 17082 (2017).

4. Podgomy, P. C. \& McLaren, L. Public perception and scientific evidence for perceived harms/risks of community water fluoridation: an examination of online comments pertaining to fluoridation cessation in Calgary in 2011. Can.J. of Public Health. 106, 413-425 (2015).

5. Frengstad, B., Banks, D. \& Siewers, U. The chemistry of Norwegian groundwaters:IV.The dependence of element concentrations in crystalline bedrock groundwaters. Sci Total Environ 277, 101-117 (2001).

6. Fallahzadeh, A. R., Miri, M., Taghavi, M. \& Gholizadeh, A. Spatial distribution and probabilistic risk assessment of exposure to fluoride in drinking water. Food and Chemical Toxicology 113, 314-321 (2018).

7. Selinus, O, Finkelman, R. B. \& Centeno, J. A. Principles of medical geology (Edtior: Nriagu, J O. Encyclopedia of environmental health, Elsevier, 669-676 (2011).

8. Barbier, O., Arreola-Mendoza, I. \& Del Rajo, I. M. Molecular mechanism of fluoride toxicity. Chem.Biol.Interact 188, 319-333 (2010).

9. Zhang, S. et al. Excessive apoptosis and defective autuphagy contribute to developmental testicular toxicity induced by fluoride. Environ. Pollut. 212, 97-104 (2016). 
10. Ge, Y., Ning, H., Wang, S. \& Wang, J. DNA damage in thyroid gland cells of rats exposed to long term intake of high fluoride and low iodine. Fluoride 38, 318-323 (2005).

11. Augustan, A. \& Berger, T. Assessing the risk of an excess fluoride intake among Swedish Children in households with private wells - Expanding static single source methods to a probabilistic multi exposure pathway approach. Environment International, 192-199 (2014).

12. Hamilton, M. Water fluoridation: a risk assessment perspective.J. Env. Health. 54, 27-32 (1992).

13. Choi, A. L., Sun, G., Zhang, Y. \& Grandjean, P. Developmental fluoride neurotoxicity: a systematic review and meta-analysis.Environ Health Perspect, 120:1362-1368 (2012).

14. Haung, C., Niu, R. \& Wang, J. Toxic effects of sodium fluoride on reproductive function in male mice. Fluoride 40 (2007).

15. Shashi, A. Biochemical effects of fluoride on thyroid gland during experimental fluorosis. Fluoride 21, 127-130 (1988).

16. McLaren, J. R. Possible effects of fluoride on the thyroid. Fluoride 9, 105-116 (1976).

17. Chiba, F. Y., Garbin, C. A. S. \& Sumida, D. H. Effect of fluoride intake on carbohydrate metabolism, glucose intolerance and insulin signalling. Fluoride 45, 236-231 (2012).

18. Trivedi, N., Mithal, A., Gupta, S. K. \& Godbole, M. M. Reversible impairment of glucose tolerance in patients with endemic fluorosis. Fluoride collaborative study group, Diabetologia 36, 826-828 (1993).

19. Rigalli, A., Ballina, J. C., Roveri, E. \& Puche, R. C. Inhibitory effect of fluoride on the secretion of Insulin. Calcif Tissue Int 46 333-338 (1990).

20. Grucka-Mamoczar et al. Lipid balance in rats with fluoride-induced hyperglycemia. Fluoride 37(3), 195-200 (2004).

21. Dey, S. \& Giri, B. Fluoride Fact on Human Health and Health Problems: A Review. Medical and Clinical Reviews 2(1), 2 (2016).

22. Aghaei, M., Derakhshani, R., Raoof, M., Dehghani, M. \& Mahvi, A. H. Effect of fluoride in drinking water on birth, height and weight: an ecological study in Kerman Province, Zarand County, Iran. Fluoride 48, 160-168 (2015).

23. Bajpai, J. Fluoride carcinogenesis: The jury is still out! South Asian J Cancer. 2(4), 192, https://doi.org/10.4103/2278-330X.119881 (2013).

24. Kharab, S., Sandhu, R. \& Kundu, Z. S. Fluoride levels and osteosarcoma. South Asian J Cancer 1, 76-7 (2012).

25. Cohn, P. D. A brief report on the association of drinking water fluoridation and the incidence of osteosarcoma among young males. New Jersey Department of Health Environment, Health Service. 1-17 (1992).

26. Dobardaran, S. Particulate air borne fluoride from an aluminium production plant in Arak, Iran. Fluoride 42, 228 (2009).

27. WHO - World Health Organization. Guidelines for drinking water quality, World Health Organization, Third Edition, Vol. 1, Geneva (2004).

28. WHO - World Health Organization. Trace Elements in Human Nutrition and Health, Geneva (1996).

29. Means B. Risk assessment guidance for Superfund Volume 1.Human Health Evaluation Manual Part A. Interim Report (Final). Office of Emergency and Remedial Response, U.S.Environmental Protection Agency, Washington D. C (1989).

30. Raj, D. \& Shaji, E. Fluoride contamination in groundwater resources of Alleppey. Southern India.Geosci.Front. 8, 117-124 (2017).

31. Kumar, S., Venkatesh, A. S., Singh, R., Udayabhanu, G. \& Saha, D. Geochemical Signatures and isotopic systematics constraining dynamics of fluoride in groundwater across Jamui district, Indo-Gangetic alluvial plains, India. Chemosphere. 205, 493-505 (2018).

32. GSI - Geological Survey of India. A Report on Geophysical survey to delineate the magnetite occurrences around Manjos village, Jamui district, Bihar (2007).

33. CGWB -Central Ground Water Board. Report on the hydrogeological conditions in Jamui-Sikandra-Malaipur area, Monghyr district, Bihar (1983).

34. APHA - American Public Health Association. Standard Methods for the Examination of Water and Waste Water, Washington, DC (2012).

35. USEPA - US Environmental Protection Agency. Reference Dose (RfD): Description and use in health risk assessments, http://www. epa.gov/iris/rfd.htm (1993).

36. Bowman, C. A., Bobrowsky, P. T. \& Selinus, O. Medical geology: new relevance in the earth sciences. Episodes 26, 4 (2003).

37. Uras, Y., Uysal, Y., Arikan, Y. A., Kop, A. \& Caliskan, M. Hydrogeochemistry of the drinking water sources of Derebogazi village (Kahramanmaras) and their effects on human health. Environ Geochem Health. https://doi.org/10.1007/s10653-014-9659-7 (2014).

38. Selinus, O, Finkelman, R. B \& Centeno, J. A. Principles of Medical Geology, Encyclopedia of Environmental Health, $2^{\text {nd }}$ Edition. https://doi.org/10.1016/B978-0-12-409548-9.11715-4 (2018).

39. Adimalla, N. \& Venkatayogi, S. Mechanism of fluoride enrichment in groundwater of hard rock aquifers in Medak, Telangana State, South India. Environ. Earth Science, 76-45 (2016)

40. USEPA - US Environmental Protection Agency. Risk assessment guidance for superfund, volume 1: human health evaluation manual (part A) ((EPA/540/1-89/002: interim final). Washington DC: Office of Emergency and Remedial Response (1989).

41. BIS - Bureau of Indian Standards, IS: 10500. Indian Standard for Drinking Water Specification. Second Revision, New Delhi (2012).

42. Reddy, A. G. S., Reddy, D. V. \& Kumar, S. M. Hydrogeochemical processes of fluoride enrichment in Chimakurthy pluton, Prakasham District, Andhra Pradesh. Environ. Earth Sci. 75, 663 (2016).

43. Vikas, C., Kushwaha, R., Ahmad, W., Prasannakumar, V. \& Rajesh, C. Genesis and geochemistry of high fluoride bearing groundwater from a semi-arid terrain of NW India. Environmental Earth Sci. 68, 289-305 (2013).

44. Soltan, M. E. Evaluation of groundwater quality in Dakhla Oasis (Egyptian Western Desert). Environmental Monitoring and Assessment 57, 157-168 (1999).

45. Narsimha, A. \& Sudarshan, V. Contamination of fluoride in groundwater and its effect on human health: a case study in hard rock aquifers of siddipet,Telangana state,India,Appl Water Sci, https://doi.org/10.1007/s13201-016-0441-0 (2016).

46. Yelidji, Y. et al. Hydrogeological mechanism governing the mineralization and elevated fluoride contents in precambarian crystalline aquifer groundwater in central benin,Western. Africa, Environ Earth Sci. 76, 691 (2017).

47. Carrilo Rivera, J. J., Cardona, A. \& Edmunds, W. M. Use of abstraction regime and knowledge of hydrogeological conditions to control high fluoride concentration in abstracted groundwater.San Louis Potosi Basin,Mexico. J Hydrology 261, 24-47 (2002).

48. Kumar, P., Singh, C. K., Chitresh, S., Mishra, B. \& Sharma, T. Evaluation of Aqueous Geochemistry of Fluoride enriched groundwater: A case study from Patan district, Gujarat. Water. Science 2, 215-229 (2017).

49. Chuah, J. C. et al. Fluoride a naturally occurring health hazard in drinking water resources of the Northern Thailand. Science of the total Environment. 545-546, 266-279 (2016).

50. Kim, K. \& Jeong, J. Y. Factors influencing natural occurrence of fluoride rich groundwaters: a case study in the southeastern part of the Korean peninsula. Chemosphere 58, 1399-1408 (2005).

51. Maniknandan, S. et al. A study on the high fluoride concentration in the magnesium rich waters of hard rock aquifer in Krishnagiri district,Tamiinadu India,Arab J Geosci, https://doi.org/10.1007/s12517-012-0752-x (2012).

52. Dharmagunawardhane, H. A., Malaviarachchi, S. P. K. \& Burgess, W. Fluoride content of minerals in gneissic rocks at an area of endemic dental fluorosis in Sri Lanka: estimates from combined petrographic and electron microprobe analysis. Ceylon Journal of Science 45(1), 57-66, https://doi.org/10.4038/cjs.v45i1.7364 (2016).

53. Raju, N. J., Dey, S. \& Das, K. Fluoride contamination in groundwaters of Sonbhadra District, Uttar Pradesh, India. Current Science 96, 979-985 (2009).

54. Chae, G., Yurt, S., Kwon, M., Kim, Y. \& Mayer, B. Batch dissolution of Biotite and Granite in water: implication for fluoride geochemistry in groundwater. Geochem J 40, 95-102 (2006).

55. O’Donnell, T. A. Fluorine in comprehensive inorganic chemistry (Vl. II).Oxford Great Britain: Pergamon Press Ltd. (1975). 
56. Sreedevi, P. D., Ahmed, S., Made, B., Ladous, E. \& Gandolfi, J. M. Association of hydrogeological factors in temporal variation of fluoride concentration in a crystalline aquifer in India. Environmental Geology 50, 1-11 (2006).

57. Jacks, G., Bhattacharya, P., Chaudhary, V. \& Singh, K. P. Controls on the genesis of some high- fluoride groundwaters in India. Applied Geochemistry 20, 221-228 (2005).

58. Singh, R., Syed, T. H., Kumar, S., Kumar, M. \& Venkatesh, A. S. Hydrogeochemical assessment of surface and groundwater resources of Korba coalfield, Central India: environmental implications. Arab J. Geosci 10, 318 (2017).

59. Guissouma, W., Hakami, O., Al -Rajab, J. A. \& Tarhouni, J. Risk assessment of fluoride exposure in drinking water of Tunisia. Chemosphere 177, 102-108 (2017).

60. Huang, D. et al. Probabilistic risk assessment of Chinese residents exposure to fluoride in improved drinking water in endemic fluorosis areas. Environ Pollut. 222, 118-125 (2017).

61. Aghapour, S., Bina, B., Tarrahi, M. J., Amiri, F. \& Ebrahimi, A. Distribution and Health risk assessment of natural fluoride of drinking groundwater resources of Isfahan,Iran using GIS, Environ. Monit. Assess, 190-137 (2018).

62. He, S. \& Wu, J. Hydrogeochemical characteristics, Groundwater quality, and health risks from Hexavalent chromium and nitrate in groundwater of Huanhe formation in Wuqi County, Northwest China. Exposure and Health. https://doi.org/10.1007/s12403-0180289-7 (2018).

63. Levy, M. S. et al. Patterns of Fluoride intake from birth to 36 months. Journal of Public Health Dentistry, vol. 61, No.270-77 (2001).

64. Martínez-Acuña, M. I., Mercado-Reyes, M., Alegría-Torres, J. A. \& Mejía-Saavedra, J. J. Preliminary human health risk assessment of arsenic and fluoride in tap water from Zacatecas, México. Environ Monit Assess 188(8), 476 (2016).

65. Adimalla N. \& Peiyue Li. Occurrence, health risks, and geochemical mechanisms of fluoride and nitrate in groundwater of the rockdominant semi-arid region, Telangana State, India. Human and Ecological Risk Assessment: An International Journal, https://doi. org/10.1080/10807039.2018.1480353 (2018)

66. Dissanayake, C. B. The Fluoride Problem in the Groundwater of Sri Lanka-Environmental Management and Health. Int. J. Environ. Stud. 38, 137-156 (1991).

67. Ali, S. et al. Concentration of fluoride in groundwater of India: A systematic review, meta-analysis and risk assessment. Groundwater for Sustainable Development, 9, https://doi.org/10.1016/j.gsd.2019.100224 (2019).

68. Ganyaglo, S. Y. et al. Groundwater fluoride contamination and probabilistic health risk assessment in fluoride endemic areas of the Upper East Region, Ghana. Chemosphere 233, 862-872 (2019).

69. Marshall, E. The Fluoride Debate: One More Time. Science 247, 276-277 (1990).

70. Centers for Disease Control and Prevention. CDC statement on water fluoridation and osteosarcoma, http://www.cdc.gov/ fluoridation/safety/osteosarcoma.htm (2009).

71. Prystupa, J. A current literature review. An NRC and ATSDR based review of safety standards for exposure to fluorine and fluorides Toxicology Mechanisms and Methods. Fluorine 21, 103-170 (2011).

72. NIC dictionary of cancer terms, https://www.cancer.gov/publications/dictionaries/cancer-terms/def/osteosarcoma.

73. USEPA - US Environmental Protection Agency. Human Health Evaluation Manual, Supplemental Guidance: Update of Standard Default Exposure Factors, OSWER Directive 9200.1-120. United States Environmental Protection Agency, Washington, DC (2014).

74. ICMR - Indian Council of Medical Research. Nutrient requirements and recommended dietary allowances for Indians. A report of the Expert group of the Indian Council of Medical Research (2009).

75. WHO - World Health Organization. World health statistics. ISBN 978924156458 8, Geneva (2013).

\section{Acknowledgements}

The authors express sincere thanks to the IIT (ISM), Dhanbad and CGWB for the facilities extended towards publication of this paper. The ideology addressed in this paper solely belongs to the authors only and not necessarily of their organizations.

\section{Author contributions}

Mr. Suresh Kumar (saday_suresh@yahoo.co.in), Central Ground Water Board, Patna, India has carried out field work, and labaratory analysis and worked out on fluoride contamination and related health implications, besides compilation of the paper. Dr. Rambabu Singh (rambabusingh2@gmail.com), Central Mine Planning and Design Institute Limited, Bilaspur, India has coordinated the research work and contributed to bring the paper to the current form in all aspects of data analyses and interpretation. Prof. (Dr.). A. S. Venkatesh (asvenkatesh@iitism. ac.in), Department of Applied Geology, Indian Institute of Technology (Indian School of Mines), Dhanbad, India is the corresponding author of the paper. He has contributed to the paper, being a subject expert, besides supervising the entire work carried out during field survey and lab experiments as well as interpretation of results. Prof. (Dr.). G. Udayabhanu (udayabhanu@iitism.ac.in), Department of Chemistry, Indian Institute of Technology (Indian School of Mines), Dhanbad, India has supervised the analysis part and contributed to interpretation of major ion chemistry. Dr. P R Sahoo (prabodha@iitism.ac.in), Department of Applied Geology, Indian Institute of Technology (Indian School of Mines), Dhanbad, India has carried out microscopic observations of rock specimen study in order to identify the possible geogenic source of fluoride contribution to groundwater.

\section{Competing interests}

The authors declare no competing interests.

\section{Additional information}

Supplementary information is available for this paper at https://doi.org/10.1038/s41598-019-52812-3.

Correspondence and requests for materials should be addressed to A.S.V.

Reprints and permissions information is available at www.nature.com/reprints.

Publisher's note Springer Nature remains neutral with regard to jurisdictional claims in published maps and institutional affiliations. 
(c) (i) Open Access This article is licensed under a Creative Commons Attribution 4.0 International License, which permits use, sharing, adaptation, distribution and reproduction in any medium or format, as long as you give appropriate credit to the original author(s) and the source, provide a link to the Creative Commons license, and indicate if changes were made. The images or other third party material in this article are included in the article's Creative Commons license, unless indicated otherwise in a credit line to the material. If material is not included in the article's Creative Commons license and your intended use is not permitted by statutory regulation or exceeds the permitted use, you will need to obtain permission directly from the copyright holder. To view a copy of this license, visit http://creativecommons.org/licenses/by/4.0/.

(C) The Author(s) 2019 